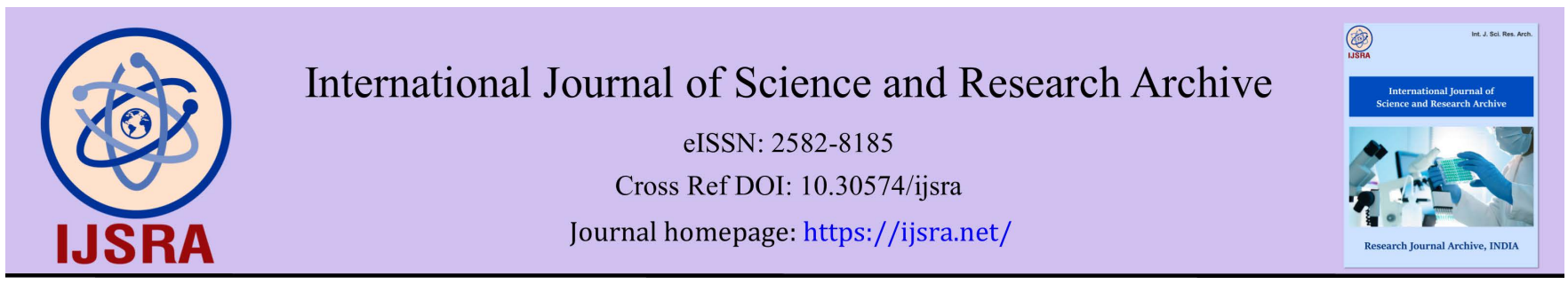

(RESEARCH ARTICLE)

\title{
Characterization of antibiotic resistance of Staphylococcus aureus isolated from patients with diabetic foot ulcers in Wasit Province
}

\author{
Rana H Raheema ${ }^{1,}{ }^{*}$, Hassan Khalil Melek ${ }^{2}$ and Atheer Tayeb Jassim ${ }^{1}$ \\ ${ }^{1}$ Department of Medical Microbiology Faculty of Medicine / University of Wasit, Iraq. \\ 2 Department of Surgery Faculty of Medicine / University of Wasit, Iraq.
}

International Journal of Science and Research Archive, 2021, 03(02), 201-208

Publication history: Received on 22 September 2021; revised on 19 October 2021; accepted on 21 October 2021

Article DOI: https://doi.org/10.30574/ijsra.2021.3.2.0146

\begin{abstract}
Diabetic foot ulcers are one of the most common public health issues worldwide, putting a social strain on those who suffer from them; chronic ulcers that lead to amputation are a severe disease that can reduce diabetic patients' quality of life. A total of seventy-five samples were collected from diabetic foot ulcer with age (30 - 89) years, during the period from $1^{\text {st }}$ October 2020 to $15^{\text {th }}$ January 2021, admitted to Al-Karama teaching hospital and private clinics in Wasit province. The results revealed that the frequency among males 50 (67\%) more than female 25 (33\%).The sample distribution according to age it appears high (42.7\%) with group (50-59) years. The results shows that Gram negative bacteria reveals a high rate $57.4 \%(\mathrm{n}=35)$ which includes $K$. pneumoniae that show a high percentage $24 \%(\mathrm{n}=18)$, then E.coli $13.2 \%(\mathrm{n}=10)$. followed, P.aeruginosa $4.0 \%(\mathrm{n}=3)$ and P.mirabilis $2.7(\mathrm{n}=2)$ and A.baumannii $2.7 \%(\mathrm{n}=2)$. While Gram-positive bacteria recorded $42.6 \%(n=26)$, which include $S$. aureus was the most isolated bacteria in this study with percentage $33.3 \%(\mathrm{n}=25)$ followed by streptococcus group $B 1.4 \%(\mathrm{n}=1)$.
\end{abstract}

Methicillin resistant Staphylococcus aureus was recorded with $92.3 \%$ in all isolates and results of MRSA isolates antibiotic susceptibility for S. aureus as shown: the maximum resistance level to the Oxacillin (100\%), penicillin (100 $\%)$, cefoxitin (92.3\%), vancomycin (61.5\%), clindamycin (61.5\%), followed by gentamicin (53.8 \%), erythromycin $(53.8 \%)$, while the lowest resistance with ciprofloxacin $(38.4 \%)$. The maximal S. aureus sensitivity has been to Trimethoprim-Sulfamethoxazole (57.8\%), vancomycin (38.5\%), ciprofloxacin (30.7 \%) and gentamicin (34.6\%). DNA of twenty-five isolates $S$. aureus were extracted, also purity and concentration were confirmed with Nanodrop, the purity of the nucleic acid in the samples ranged between 1.8-2, while its concentration ranged from (50-360 mg / $\mu$ l).

Resistance genes possessed by the $S$. aureus isolates were: $\operatorname{mec} A(96 \%)$, ermC (40\%), $\operatorname{msr} A(8.0 \%)$ and $\operatorname{aac}\left(6^{\prime}\right)$-aph( $\left(2^{\prime \prime}\right)$ $(16 \%)$. while $\operatorname{erm} A$ and $v a n A$ genes were absent among all isolates. In conclusion, the findings of the present study revealed that most studied isolates which had multiple antibiotic resistances.

Keywords: Diabetic foot ulcer; S. aureus; Characterization; Antibiotic resistance genes.

\section{Introduction}

A foot affected by ulceration is associated with neuropathy and peripheral arterial disease of the lower limb in a patient with diabetes. As well as diabetic foot ulcer usually fail to heal and lead to lower extremity amputation (Yazdanpanah et al., 2015). Diabetic foot ulcers are one of the most common public health issues worldwide, putting a social strain on those who suffer from them. Chronic ulcers that lead to amputation are a severe disease that can reduce diabetic patients' quality of life (Rathur and Boulton, 2007). Practically everyone will have one or more Staph aureus infections in his or her lifetime (20-50\%) of the human population are often colonized with Staph aureus in addition it is a major

\footnotetext{
${ }^{*}$ Corresponding author: Rana H. Raheema

Wasit university , College of medicine, Medical microbiology ,wasit province ,Iraq .

Copyright $(2021$ Author(s) retain the copyright of this article. This article is published under the terms of the Creative Commons Attribution Liscense 4.0.
} 
pathogenic bacteria responsible for community-acquired and nosocomial infections, it is one of the most common human pathogenic bacteria that cause different sequelae of infections in both genders and in all age groups (Suhaili et al., 2018). Methicillin resistant $S$. aureus creates resistance to the beta-lactam antibiotics through the gaining of the $m e c A$ gene that encodes the penicillin-binding protein 2 a, having an extensively diminished affinity for the $\beta$-lactam antibiotics, hence conferring the resistance of $\beta$-lactam. Sources have been evaluated by cefoxitin disc diffusion test and the PCR detection of mecA gene (Wijesundara et al., 2019).

\section{Material and methods}

Totally seventy-five samples were collected from diabetic foot ulcer with age (30 - 89) years, during the period from $1^{\text {st }}$ October 2020 to ${ }^{15}$ th January 2021 admitted to Al-Karama teaching hospital and private clinics in Wasit province. Isolation the Swab samples were collected from diabetic foot ulcer with age (30 - 89) years. Culture on Manitol salt agar, Blood agar and aerobically incubated for $24 \mathrm{~h}$ at $37^{\circ} \mathrm{C}$ (Bhatia, 2008). The isolated bacteria were identified according to morphological, biochemical tests and Vitek2. Antibiotic Susceptibility testing this test has been conducted by the KirbyBauer process on the Muller Hinton agar (Bauer et al., 1966) and the results have been interpreted based on the (CLSI, 2020). Primers were supplied by the manufacturer (Integrated DNA Technologies, USA) as lyophilized powder in eppendorf tubes $(1.5 \mathrm{ml})$ as the procedure mentioned by Dahwash et al., (2021) (Table 1).

Table 1 Primer's sequence of resistance genes

\begin{tabular}{|c|c|c|c|c|}
\hline Genes & & Primer sequences $\left(5^{\prime}-3^{\prime}\right)$ & size (bp) & Source of primer \\
\hline \multirow{2}{*}{ vanA } & $\mathrm{F}$ & GGC AAG TCA GGT GAA GAT G & \multirow{2}{*}{713} & \multirow{10}{*}{ (Cabrera et al., 2020) } \\
\hline & $\mathrm{R}$ & ATC AAG CGG TCA ATC AGT TC & & \\
\hline \multirow{2}{*}{ ermA } & $\mathrm{F}$ & TATCTT ATC GTT GAG AAG GGA TT & \multirow{2}{*}{138} & \\
\hline & $\mathrm{R}$ & CTACAC TTG GCT TAG GAT GAA A & & \\
\hline \multirow{2}{*}{$\operatorname{ermC}$} & $\mathrm{F}$ & CTT GTTGAT CAC GAT AAT TTC C & \multirow{2}{*}{189} & \\
\hline & $\mathrm{R}$ & ATC TTTTAG CAA ACC CGT ATT C & & \\
\hline \multirow{2}{*}{$m s r A$} & $\mathrm{~F}$ & TCC AATCAT TGC ACA AAA TC & \multirow{2}{*}{162} & \\
\hline & $\mathrm{R}$ & AAT TCCCTC TAT TTG GTG GT & & \\
\hline \multirow{2}{*}{$\operatorname{aac}\left(6^{\prime}\right)-\operatorname{aph}\left(2^{\prime \prime}\right)$} & $\mathrm{F}$ & TTG GGAAGA TGA AGT TTT TAG A & \multirow{2}{*}{173} & \\
\hline & $\mathrm{R}$ & CCT TTACTC CAA TAA TTT GGC T & & \\
\hline \multirow{2}{*}{ тес $A$} & $\mathrm{~F}$ & GGGATC ATAGCG TCA TTATTC & \multirow{2}{*}{527} & \multirow[t]{2}{*}{ (Poulsen et al., 2003) } \\
\hline & $\mathrm{R}$ & AAC GAT TGT GAC ACGATAGCC & & \\
\hline
\end{tabular}

\subsection{Detection of Staph. aureus Resistance genes}

This was achieved by multiplex PCR. For ermC, ermA, msrA and aac( $\left.6^{\prime}\right)-\operatorname{aph}\left(2^{\prime \prime}\right)$, mecA and vanA genes, $1 \mu \mathrm{l}(25 \mathrm{pmol} / \mu \mathrm{l})$ of forward primer and $1 \mu \mathrm{l}(25 \mathrm{pmol} / \mu \mathrm{l})$ of reverse primer were added to PCR master mix which was prepared as in Table (4) and Monoplex PCR Mixture.

\begin{tabular}{|c|c|c|c|c|c|c|c|}
\hline Table (2) Thermal c & ling prog & am for $r$ & oplex: mecA & Table (3) Thermal cy & ling prog & am for & onoplex: vanA \\
\hline PCR step & Temp. & Time & $\begin{array}{l}\text { No. of } \\
\text { cycles }\end{array}$ & PCR step & Temp. & Time & No. of cycles \\
\hline initial Denaturation & $95^{\circ} \mathrm{C}$ & $5 \mathrm{~min}$. & 1 & initial Denaturation & $94^{\circ} \mathrm{C}$ & $5 \mathrm{~min}$. & 1 \\
\hline denaturation & $95^{\circ} \mathrm{C}$ & $1 \mathrm{~min}$. & \multirow{3}{*}{32 cycle } & denaturation & $94^{\circ} \mathrm{C}$ & $1 \mathrm{~min}$. & \multirow{3}{*}{40 cycles } \\
\hline Annealing & $51^{\circ} \mathrm{C}$ & $30 \mathrm{sec}$. & & Annealing & $55^{\circ} \mathrm{C}$ & $1 \mathrm{~min}$. & \\
\hline Extensions & $72^{\circ} \mathrm{C}$ & $1 \mathrm{~min}$. & & Extensions & $72^{\circ} \mathrm{C}$ & $2 \mathrm{~min}$. & \\
\hline finale extensions & $72^{\circ} \mathrm{C}$ & $5 \mathrm{~min}$. & 1 & finale extensions & $72^{\circ} \mathrm{C}$ & $5 \mathrm{~min}$. & 1 \\
\hline Hold & $4^{\circ} \mathrm{C}$ & $\infty$ & - & Hold & $4^{\circ} \mathrm{C}$ & $\infty$ & - \\
\hline
\end{tabular}


Table 4 Thermal cycling program for multiplex pool. 4: ermC, ermA, msrA and aac(6')-aph(2")

\begin{tabular}{|l|c|c|c|}
\hline \multicolumn{1}{|c|}{ PCR step } & Temperatures & Time & No. of cycles \\
\hline initial Denaturation & $94^{\circ} \mathrm{C}$ & 3 min. & 1 \\
\hline denaturation & $94^{\circ} \mathrm{C}$ & 30 sec. & \multirow{2}{*}{30 cycle } \\
\cline { 1 - 2 } Annealing & $55^{\circ} \mathrm{C}$ & 30 sec. & \multirow{2}{*}{30} \\
\cline { 1 - 3 } Extensions & $72^{\circ} \mathrm{C}$ & 30 sec. & \multirow{2}{*}{1} \\
\hline finale extensions & $72^{\circ} \mathrm{C}$ & 4 min. & - \\
\hline Hold & $4^{\circ} \mathrm{C}$ & $\infty$ & \multirow{2}{*}{} \\
\hline
\end{tabular}

Then gel electrophoresis and documentation according to (Sambrook and Russell, 2001). Statistical analysis of data has been done with the use of SAS (Statistical Analysis System - version 9.1). In addition, the percentages have been compared with the use of Chi-square test. $\mathrm{P}<0.05$ is considered to have statistical significance.

\section{Results and discussion}

The percentage of bacterial growth, which was isolated as shown in figure (1), this results are consistent with findings from other Iraqi studies (Raheema, 2016a; and Al-Saeedi and Raheema, 2019). Also similar result was recorded by Raheema, (2016b) and Raheema, and Abed, (2019).

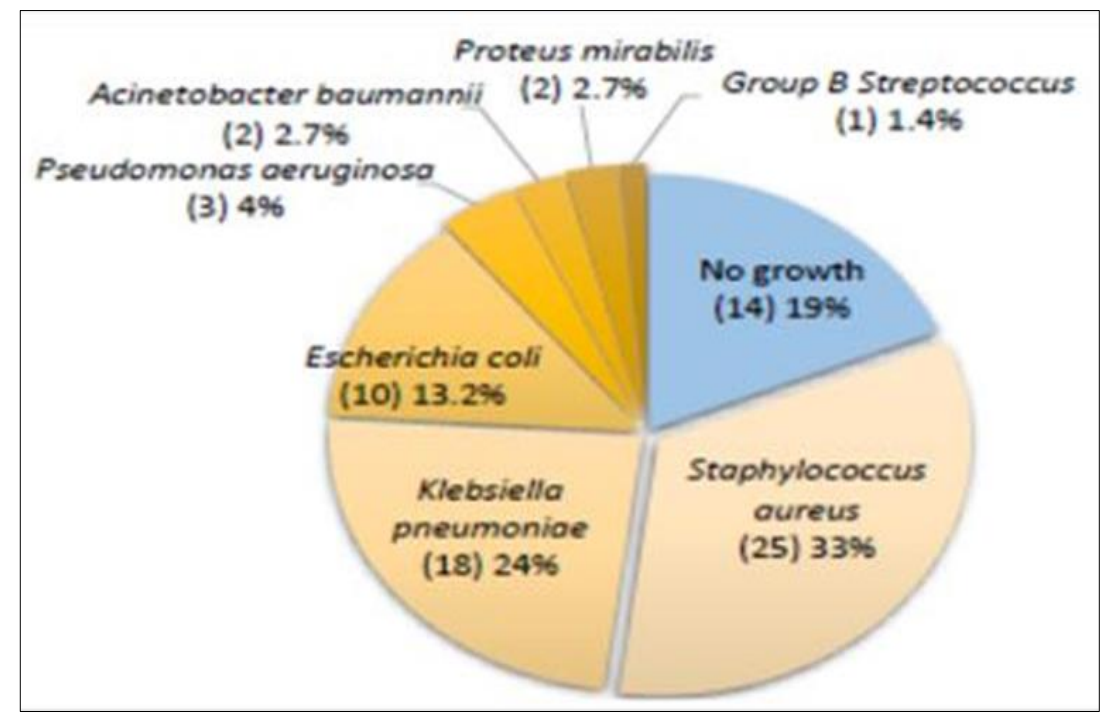

Figure 1 Distribution of bacterial species

The results of this study, MRSA showed the highest resistance for cefoxitin with 92.3\% Staphylococcus aureus espealis MRSA, has spread to all parts of the word and is become of significant concern in public health as one the most common causes of nosocomial infections (Raheema, and Qaddoori, 2020).The results of this study have been similar to results obtained by Al-Dahbi, and Al-Mathkhury, (2013) and Idbeis, (2019) who found all the isolates revealed complete resistant $(100 \%)$ to oxacillin and cefoxitin.

The results of the antibiotic susceptibility for $S$. aureus showed that the maximum resistance level to the Oxacillin $(100$ $\%)$, penicillin (100 \%) , cefoxitin (92.3\%), vancomycin (61.5\%), clindamycin (61.5\%), followed by gentamicin (53.8 $\%)$, erythromycin (53.8\%), while the lowest resistance with ciprofloxacin (38.4\%) and TrimethoprimSulfamethoxazole (38.4\%). The maximal S. aureus sensitivity has been to Trimethoprim-Sulfamethoxazole (57.8 \%), vancomycin (38.5\%), ciprofloxacin (30.7\%) and gentamicin (34.6\%) as shown in figure (2). 


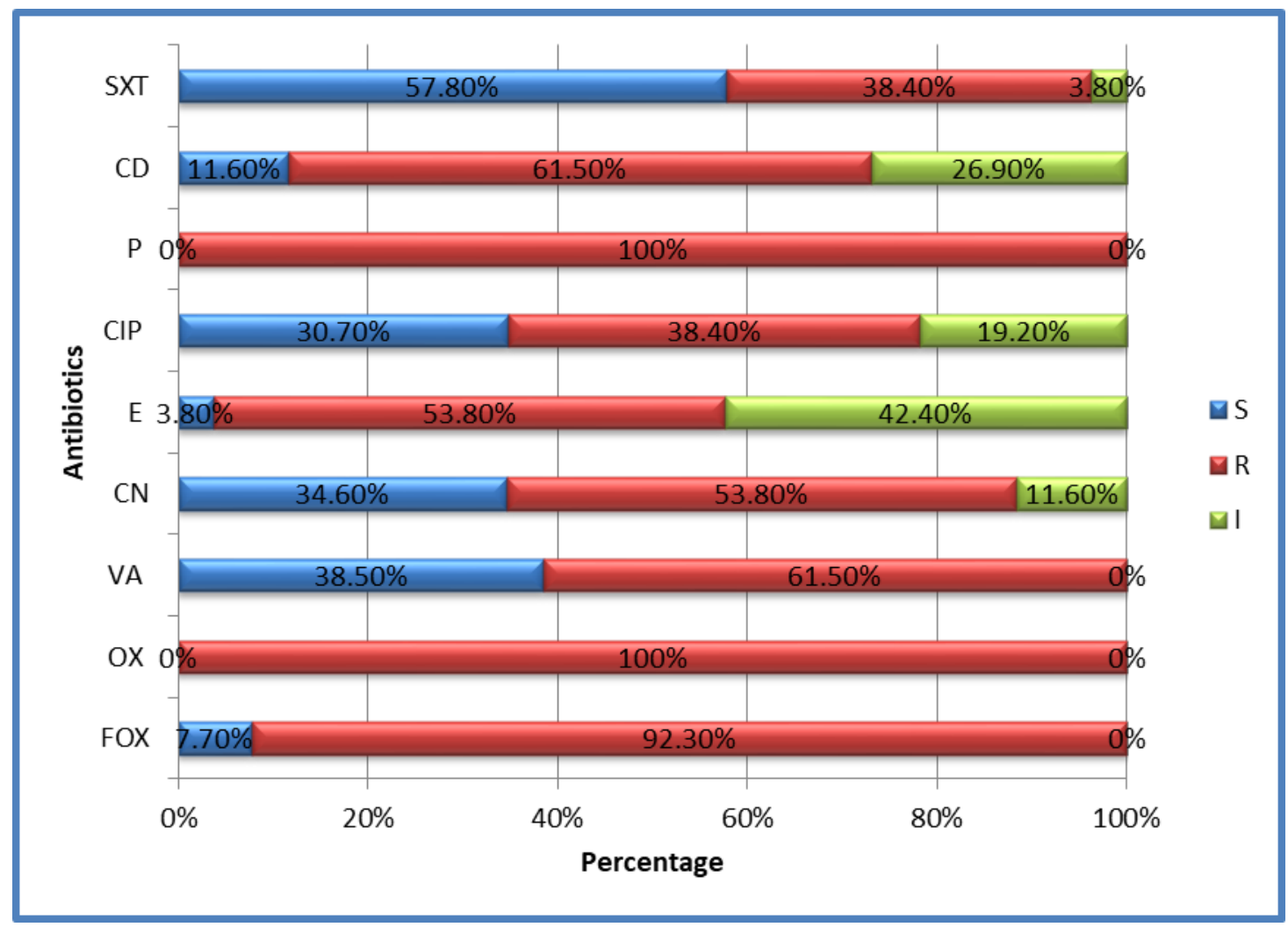

Figure 2 The percentage of resistance for S. aureus isolates against antibiotics

The results showed that (100\%) of $S$. aureus isolates were resistant for penicillin, oxacillin this result agreed with the results that had obtained in other local studies done by each of Dogramachy, (2018); Idbeis, (2019) and Khudher and Jabur (2020). The isolates appeared high levels of resistance to penicillin (100\%), also showed that $61.5 \%$ of S.aureus isolates were resistant to vancomycin; this result disagreed with results obtained by Saber et al., (2018) who found that the rate of resistance for vancomycin was $8 \%$, such resistance possibly mediated via increasing thickness the cell wall of the bacteria, making it difficult for the vancomycin to enter the cell. The mutations or mechanisms that are needed for such change in cell walls haven't been specified yet (Howden et al., 2020). Vancomycin resistance has been mediated through acquiring vanA gene from the closely related enterococci. The gene's expression permits the modifications in peptidoglycan precursors that decrease the vancomycin binding affinity (Zhu et al., 2010).

The susceptibility rate of the isolates toward the Cefoxitin was 7.7\%, this result somewhat near to the study of Al-Khafaji, (2013) who found that $S$. aureus isolates were highly resistant to methicillin in $92.3 \%$. Methicillin-resistant may harbor the genes of the resistance in other genome sites and on plasmids, in addition to carrying the genes of resistance in SCCmec (Deurenberg and Stobberingh, (2008) which is a possible explanation of the reason why the MRSA could resist more than 1 antibiotic besides the $\beta$-lactam (Multidrug Resistant). Reducing the permeability of the cell wall, production of chromosomal and plasmid mediated beta - lactamase are considered to be the main mechanism of resistance to methicillin (Katzif et al., 2005). In the current study, multi resistant isolates were divided into MDR, XDR and possible PDR according to the criterion proposed by Magiorakos et al., (2012), which were MDR 52\%, XDR 32 \% and PDR 4 \%.

Regarding mecA gene in the present study, its prevalence was $96 \%$ among S. aureus clinical isolates (Figure 3). Polymerase chain reaction amplification of mecA gene has been applied as the " gold standard" for identification of MRSA (Jonas et al., 2002). The prevalence of mecA gene was in agreement with previously published studies that showed mecA prevalence to be $94.33 \%$ among S. aureus isolates (Raheema, 2019) and disagree with Kareem et al., (2015) who reported $75.5 \%$. 


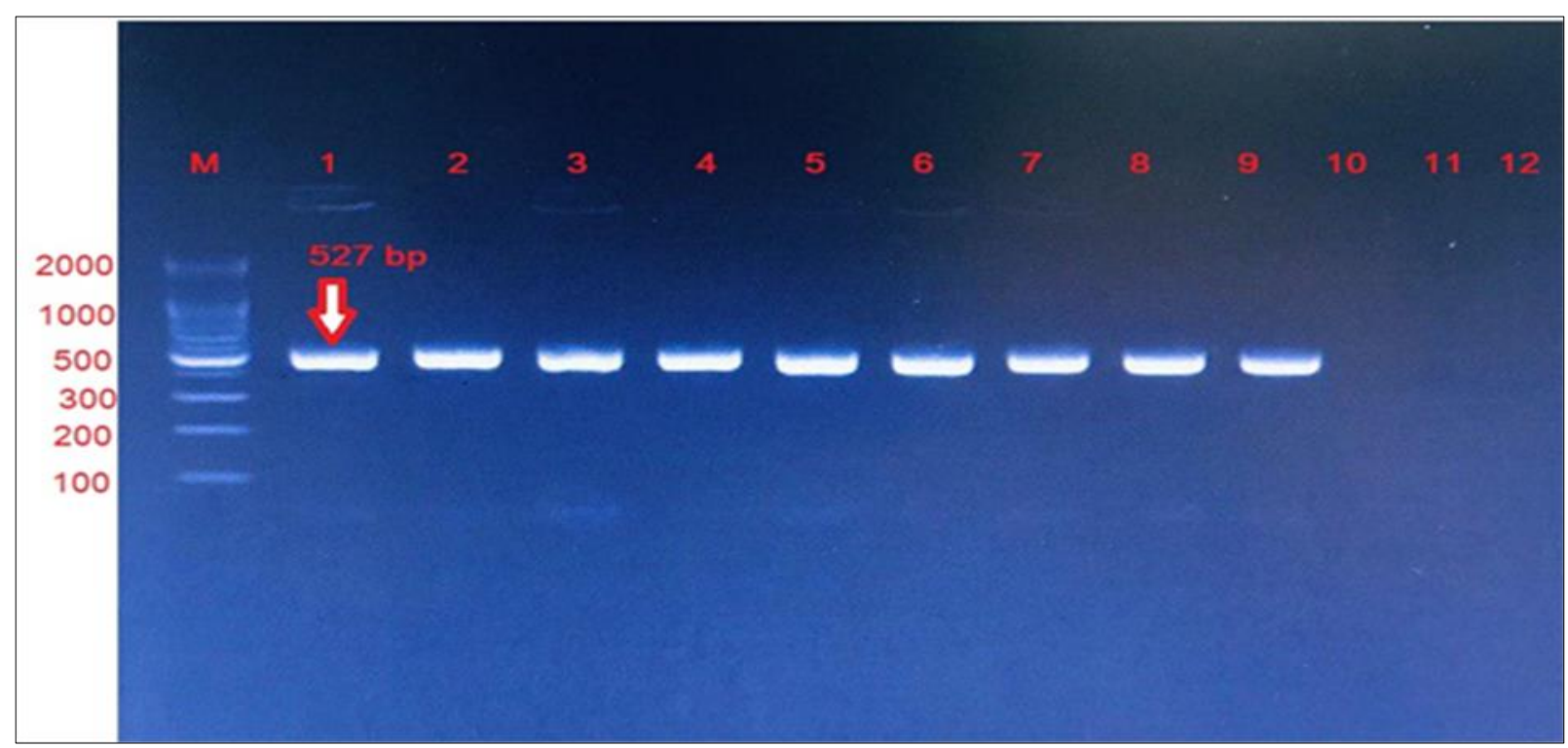

Figure 3 Gel electrophoresis of amplified mecA gene from S. aureus traditional PCR. Agarose 2\%, $70 \mathrm{~V} / \mathrm{cm} \mathrm{for} 40 \mathrm{~min}$, which has been stained by the ethidium bromide dye and observed on an ultraviolet trans-illuminator. Lane (M): 100bp DNA ladder. Lane (1-12 ): Amplicons mecA (527) bp gene

In the present study, erythromycin was in high frequencies (40\%) with ermC, msrA (8.0 \%) whereas, no PCRamplification products with ermA Figure (4). S. aureus clinical isolates. This study was in accordance with different studies that had shown the ermA gene (7.35\%) prevalence, of erm C gene $(5.88 \%)$ and no ermB gene that has been recovered from the isolates of the $S$. aureus (Al-Hasnawy, 2020) in Iraq also the most prevalent resistance gene determinates was ermC (88.4\%) among MRSA isolates. While the frequency of ; ermA and msrA were (76.9\%) and (80.7\%), respectively (Cabrera et al., 2020) and disagree with Adwan et al., (2014) in Spain who found ermC (61.5\%) and $m s r A$ genes $(23.1 \%)$.

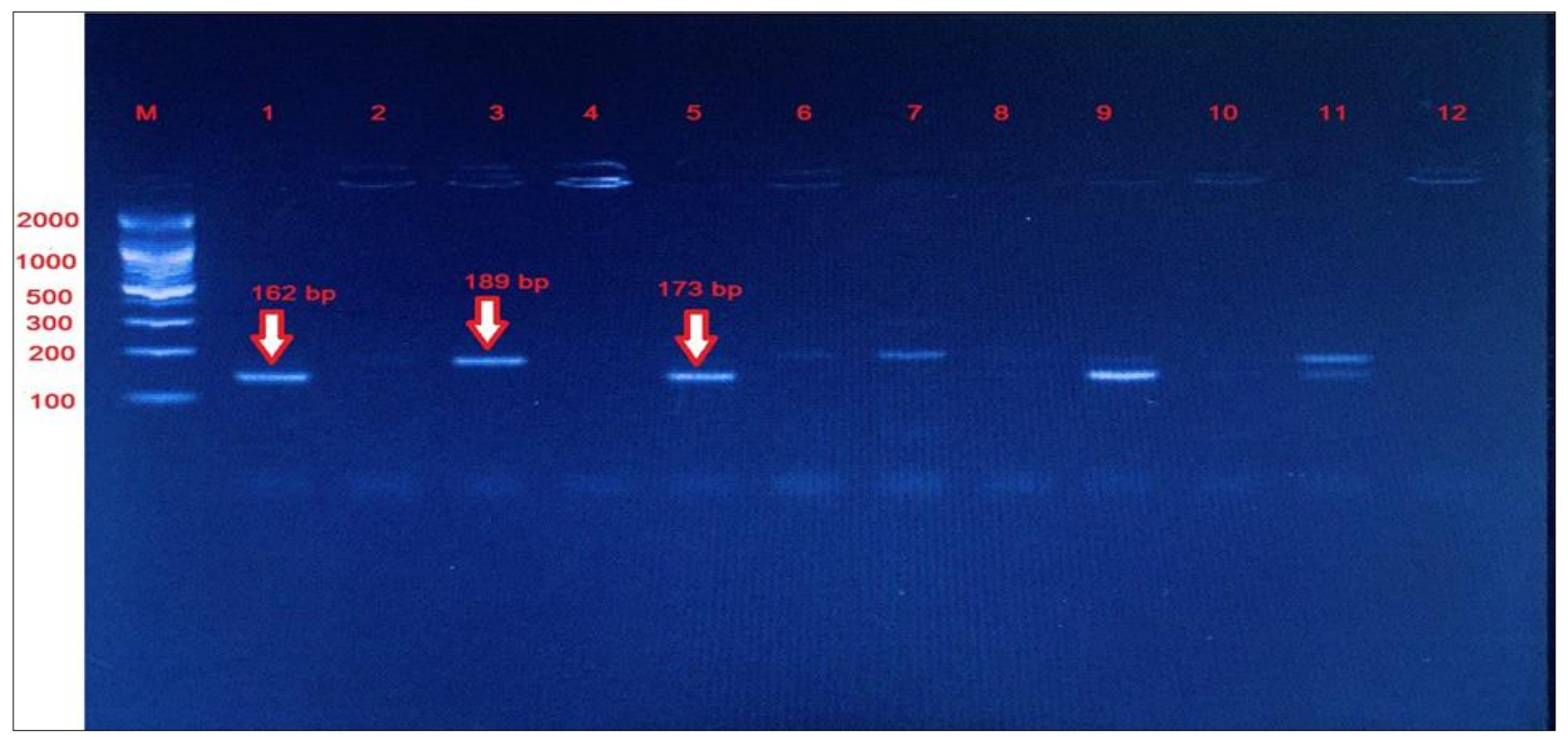

Figure 4 Gel electrophoresis of amplified ermC, msrA, aac(6)aph(2) gene from S. aureus traditional PCR. Agarose 2\%, $70 \mathrm{~V} / \mathrm{cm}$ for $40 \mathrm{~min}$, which has been stained by the ethidium bromide dye and observed on an ultraviolet transilluminator. Lane (M): 100bp DNA ladder. Lane (1-12 ): Amplicons ermC (189) bp, msrA (162) bp , aac(6)aph(2)( 173) bp gene

Regarding vanA gene in the present study, no specific band detected for vanA genes $S$. aureus which disagreed with Zhang et al., (2004) who found (1.8\%) also disagreed with the absence of Vancomycin resistance is due to the lack of vanA and vanB genes (Al-sherees, 2019). Regarding aac $\left(6^{\prime}\right)-\operatorname{aph}\left(2^{\prime \prime}\right)$ gene in the present study, its prevalence was (16 
$\%$ ) among S. aureus clinical isolates (Figure 4). This result was in accordance with different researches conducted by Ardic et al., (2006) 34\%, Goudarzi et al., (2019) in Japan.

\section{Conclusion}

In conclusion, in studied the $S$. aureus is the findings of the present study revealed that most studied isolates which had multiple antibiotic resistances. Phenotypic and genotypic indicated the wide spread prevalence of Methicillin resistant Staphylococcus aureus among all $S$. aureus isolates, also molecular approaches are more reliable than traditional methods for detection.

\section{Compliance with ethical standards}

\section{Acknowledgments}

The first author acknowledges with gratitude the support provided by college of medicine, wasit university.

\section{Disclosure of conflict of interest}

The authors declared no conflict of interest.

\section{References}

[1] Adwan G, Adwan K, Jarrar N, Amleh A. Molecular detection of nine antibiotic resistance genes in methicillin resistant Staphylococcus aureus isolates. Romanian Archives of Microbiology and Immunology. 2014; 73(1-2): 9-18.

[2] Al-Dahbi AM, Al-Mathkhury HJ. Distribution of Methicillin Resistant Staphylococcus aureus in Iraqi patients and Healthcare Workers. Iraqi Journal of Science. 2013; 54(2): 293-300.

[3] Al-Hasnawy H, KA. Occurrence of erm and msra genes in inducible clindamycin resistance of methicillin resistant staphylococcus aureus isolated from different clinical specimens in al hilla, Iraq. Biochemical and Cellular Archives. 2020; 656-685.

[4] Khudher KKK, Jabur SG. The prevalence of some virulence plasmid genes in Staphylococcus aureus infection. Plant Archives. 2020; 20(2): 8851-8862.

[5] Al-Khafaji MHM. Detection of Enterotoxins Genes in Staphylococci Isolated from Milk and Cheese. Ph.D. Thesis. College of Science, Baghdad University. 2013.

[6] Al-Saeedi RHA, Raheema RH. Molecular Diagnosis of some Virulence Genes in Pseudomonas aeruginosa Clinical Isolates in Wasit Province. Indian Journal of Public Health. 2019; 10(04).

[7] Al-sherees HAA. Molecular Diagnosis of Aminoglycoside Transferase Genes in Methicillin-Resistant Staphylococcus aureus (MRSA) Strains. Indian Journal of Natural Sciences. 2019; 10(58): 166-171.

[8] Ardic N, Sareyyupoglu B, Ozyurt M, Haznedaroglu T, Ilga U. Investigation of aminoglycoside modifying enzyme genes in methicillin-resistant staphylococci. Microbiological Research. 2006; 161(1): 49-54.

[9] Bauer AW, Kirby WM, Sherris JC, Tuick M. Antibiotic susceptibility testing by standardized single disc metho. Ameri. J. Clin Pathol. 1966; 45: 493-496.

[10] Bhatia RIR. Essential of medical microbiology. 4th ed. Jaypee. 2018.

[11] Cabrera R, Fernández-Barat L, Motos A, López-Aladid R, Vázquez N, Panigada M, Álvarez-Lerma F, López Y, Muñoz L, Castro P, Vila J, Torres A. Molecular characterization of methicillin-resistant Staphylococcus aureus clinical strains from the endotracheal tubes of patients with nosocomial pneumonia. Antimicrobial Resistance and Infection Control. 2020; 9(1): 43.

[12] Clinical and Laboratory Standards Institute (CLSI). Performance standards for antimicrobial susceptibility testing. In: Clinical and Laboratory Standards Institute Wayne, PA. 2020.

[13] Dahwash SM, Raheema RH, Albahadili MA, Maslat AH. Distribution of phylogenetics and virulence genes of uropathogenic Escherichia coli among urinary tract infection in pregnant women. Biochem. Cell. Arch. 2021; 21: 449-456. 
[14] Deurenberg RH, Stobberingh EE. The evolution of Staphylococcus aureus. Infection, Genetics and Evolution. 2008; 747-763.

[15] Dogramachy N. Prevalence of nasal carriage rate for methicillin-resistant Staphylococcus aureus and its antibiotic susceptibility profiles in health care workers at Nanakaly Hospital, Erbil, Iraq. Zanco Journal of Medical Sciences. 2018; 22(3): 411-419.

[16] Goudarzi M, Razeghi M, Dadashi M, Miri M, Hashemi A, Amirpour A, et al. Distribution of SCCmec types, tetracycline and aminoglycoside resistance genes in hospital-associated methicillin-resistant Staphylococcus aureus strains. Gene Reports. 2019; 16: 100454.

[17] Howden BP, Davies JK, Johnson PDR, Stinear TP, Grayson ML. Reduced vancomycin susceptibility in Staphylococcus aureus, including vancomycin-intermediate and heterogeneous vancomycin-intermediate strains: resistance mechanisms, laboratory detection, and clinical implications. Clin. Microbiol. Rev. 2010; 23: 99139.

[18] Idbeis HI. Antibiofilm Activity of Cinnamon Oil Against Biofilm Methecillin Resistance Staphylococcus aureus Isolates from Mastitis. A thesis College of Veterinary Medicine, University of Basrah, Iraq. 2019.

[19] Jonas DM, Speck FD, Daschner, H Grundmann. Rapid PCRBased Identification of[ Methicillin-Resistant Staphylococcus aureus from Screening Swabs. J .Clin.Microbiol. 2002; 40: 1821-1823.

[20] Kareem SM, Al-Jubori SS, Ali MR. Prevalence of erm genes among methicillin resistant Staphylococcus aureus MRSA Iraqi isolates. Int J Curr Microbiol Appl Sci. 2015; 4(5): 575-585.

[21] Katzif S, Lee EH, Law AB, Tzeng YL, Shafer WM. Regulates pigment production in Staphylococcus aureus through a Sig-B dependent mechanism. J. Bacteriol. 2005; 187(23): 8181-8184.

[22] Magiorakos AP, Srinivasan A, Carey RT, Carmeli Y, Falagas Mt, Giske Ct, Olsson-Liljequist B. Multidrugresistant, extensively drug-resistant and pandrug-resistant bacteria: an international expert proposal for interim standard definitions for acquired resistance. Clinical Microbiology and Infection. 18(3): 268-281.

[23] Raheema RH, Qaddoori BH. Detection of the Toxin Associated Genes of MethicillinResistant Staphylococcus Aureus Using a Multiplex PCR Assay in Wasit General Hospitals. Sys Rev Pharm. 2020; 11(10): 584-589.

[24] Raheema RH. Experimental study for the effect of Trigonellafoenum-graecum (fenugreek) seeds extract on some biochemical and histo pathological study in induced diarrhea in mice by Klebsiella pneumonia . IOSR Journal of Pharmacy. 2016; 6(2): 04-13.

[25] Raheema RH. Rapid methods for detection of methicillin-resistant staphylococcus aureus in Wasit province, lraq. Plant Archives. 2020; 20(2): 6131-6134.

[26] Raheema RH, Abed KA. Molecular identification of Virulence Genes of Staphylococcus aureus Isolated from Different Clinical Isolates. Indian Journal of Public Health Research \& Development. 2019; 10(2).

[27] Raheema RH. Effect of Pomegranate Peel Extract on some Biochemical and Histopathological Parameters in Experimental Induced Mice with Staphylococcus aureus .Journal of Animal Health and Production. 2016; 4(2): 42-49.

[28] Rathur HM, Boulton AJ. The Diabetic Foot. Clin Dermatol. 2007; 25: 109-20.

[29] Saber, Noor, Joseph Kandala, Nuha. The inhibitory effect of fluphenazine decanoate and caffeine on Staphylococcus aureus efflux pumps. Current Research in Microbiology and Biotechnology. 2018; 6(2): 15301535.

[30] Sambrook J, Russell D. Molecular Cloning: a laboratory manual, 854 Cold Spring Harbor Laboratory Press. New York. 2001; 855.

[31] Suhaili Z, Rafee PA, Mat Azis N, Yeo CC, Nordin SA, Abdul Rahim AR, Mohd Desa MN. Characterization of resistance to selected antibiotics and panton-valentine leukocidin-positive Staphylococcus aureus in a healthy student population at a Malaysian University. Germs. 2018; 8(1): 21-30.

[32] Wijesundara W, Rajapakse R, Jayatilake J, Jayatilake J. A preliminary study of mecA gene expression and methicillin resistance in staphylococci isolated from the human oral cavity. Sri Lankan Journal of Infectious Diseases. 2019; 9(1).

[33] Yazdanpanah L, Nasiri M, Adarvishi S. Literature Review on the management of diabetic foot ulcer. World J Diabetes. 2015; 6(1): 37-53. 
[34] Zhang K, Sparling J, Chow BL, Elsayed S, Hussain Z, Church DL, Gregson DB, Louie T, Conly JM. New quadriplex pcr assay for detecting methicillin and mupirocin resistance and simultaneous discrimination of Staphylococcus aureus from coagulase-negative staphylococci. Journal of Clinical Microbiology. 2004; 42(11): 4947-4955.

[35] Zhu W, Murray PR, Huskins WC, Jernigan JA, McDonald LC, Clark NC, Anderson KF, McDougal LK, Hageman JC, Olsen-Rasmussen M, Frace M, Alangaden GJ, Chenoweth C, Zervos MJ, Robinson-Dunn B, Schreckenberger PC, Reller LB, Rudrik JT, Patel JB. Dissemination of an Enterococcus Inc18-like vanA plasmid associated with vancomycin-resistant Staphylococcus aureus. Antimicrob. Agents Chemother. 2010; 54: 4314-4320. 